\title{
A Review of Gold Metallurgeny in Nigeria
}

\author{
Kankara, I. A. and Darma, M. R.
}

\begin{abstract}
Occurrence of gold in placers and primary veins is know in several areas of the western half of Nigeria from Anka and Maru in the northwest in primarily super crustal (schist's) belts. The primary gold mineralization is associated with veins, stringers, lenses, reefs and similar bodies of quartz, quartz-feldspar and quartztourmaline rocks in both the supracrustal rocks and basement. The veins range in thickness from several centimeters to a few metres, often displaying lenticular or pinch and swell (boundinage) structure and invariably steeply inclined occurring as isolated body or as parallel or echelon veins system. The gold-bearing veins are commonly associated with fractures and shear zones and mainly concordant with regional foliation trends, but may also be cross in some cases. The method adopted for the research were mainly secondary data. Results for the study show that although there are many commercial deposits of the mineral in the areas indicated but the Federal government is still not keen in making the Industry economically stronger. The paper therefore recommends full compensation to local and host communities in order to depray the cost of environmental destruction.
\end{abstract}

Keywords-Gold metallorgeny, Host Communities, Compensation, Government, Nigeria

\section{INTRODUCTION}

Geochemical Pathfinders are minerals that often formed in close association with gold. Therefore, their presence even in seemingly gold-barren rock opens up the possibility of locating a nearby gold deposit. Geochemical pathfinders are an important tool in gold exploration. Due to the fact that gold is so rare, locating it in a sample is very unlikely. Through the identification of pathfinder minerals, explorers can help determine the possibility of gold occurrences in a given area. Examples of minerals that are geochemical pathfinders for gold include silver, copper, lead, zinc, cobalt, nickel, arsenic, antimony, tellurium, selenium and mercury. Occurrence of gold in placers and primary veins is know in several areas of the western half of Nigeria from Anka and Maru in the northwest in primarily super crustal (schist's) belts [1].

The primary gold mineralization is associated with veins, stringers, lenses, reefs and similar bodies of quartz, quartzfeldspar and quartz-tourmaline rocks in both the supracrustal rocks and basement. The veins range in thickness from several centimeters to a few metres, often displaying lenticular or pinch and swell (boundinage) structure and invariably steeply inclined occurring as isolated body or as parallel or echelon veins system.

A Pre-feasibility Study is a comprehensive study of the viability of a mineral project that had advanced to a stage where the mining method, in the case of underground mining, or the pit configuration, in the case of an open pit, has been

Dr. Aliyu Ibrahim Kankara, Lecturer I, Federal University DutsinMa, Kastina State, Nigeria established, where an effective method of mineral processing has been determined, and includes a financial analysis based on reasonable assumptions of technical, engineering, legal, operating and economic factors and evaluation of other relevant factors which are sufficient for a Competent Person, acting reasonable, to determine if all or part of the Mineral resources may be classified as Mineral Reserve. Then, a feasibility study is a comprehensive study of a mineral deposit in which all geological, engineering, legal, operating, economic, social, environmental and other relevant factors together with operational factors are considered in sufficient detail. The results of the study may reasonably serve as the basis for a final decision by a proponent or financial institution to proceed with, or finance, the development of the development of the project. The confidence level of the study will be higher than that of a Pre-Feasibility Study.

\section{STUDY AREA}

Nigeria is situated in the West African region and lies between longitudes 3 degrees and 14 degrees and latitudes 4 degrees and 14 degrees. It has a land mass of 923,768 sq.km. It is bordered to the north by the Republics of Niger and Tchad; it shares borders to the west with the Republic of Benin, while the Republic of Cameroun shares the eastern borders right down to the shores of the Atlantic Ocean which forms the southern limits of Nigerian Territory (see figure 1) The $800 \mathrm{~km}$ of coastline confers on the country the potentials of a maritime power. Land is in abundance in Nigeria for agricultural, industrial and commercial activities. At its widest, Nigeria measures about $1,200 \mathrm{~km}$ from east to west and about $1,050 \mathrm{~km}$ from north to south (see figure 1) The country's topography ranges from lowlands along the coast and in the lower Niger Valley to high plateaus in the north and mountains along the eastern border. 


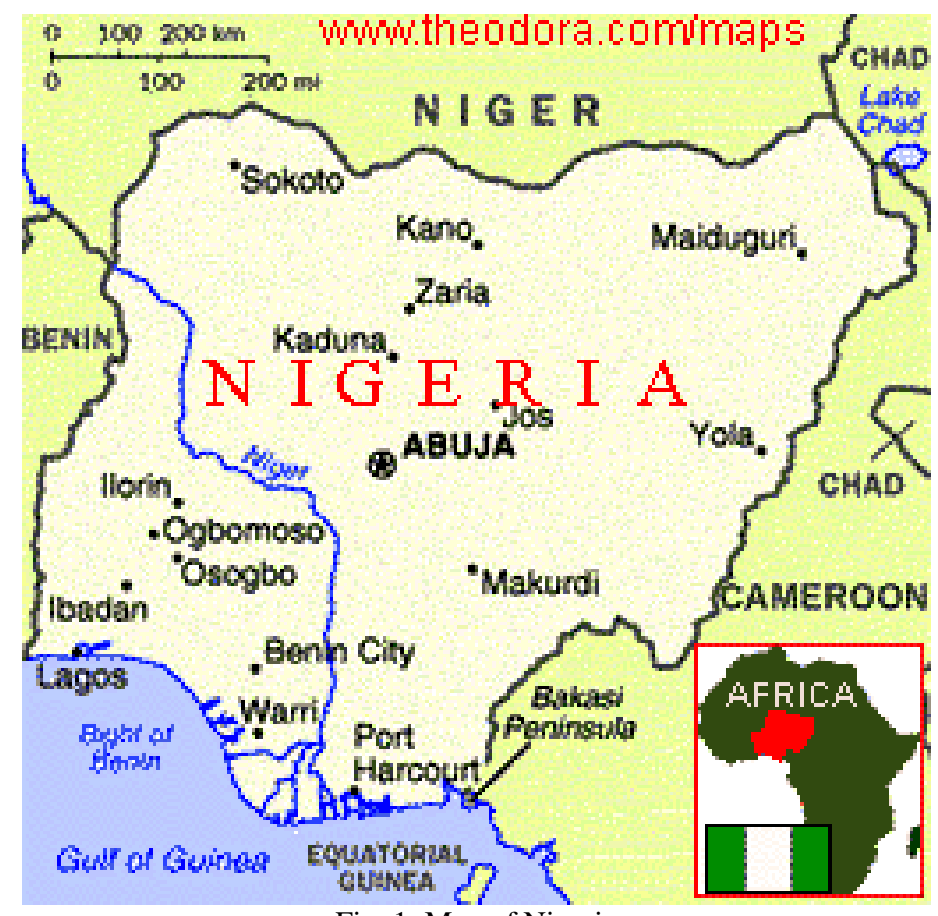

Fig. 1: Map of Nigeria

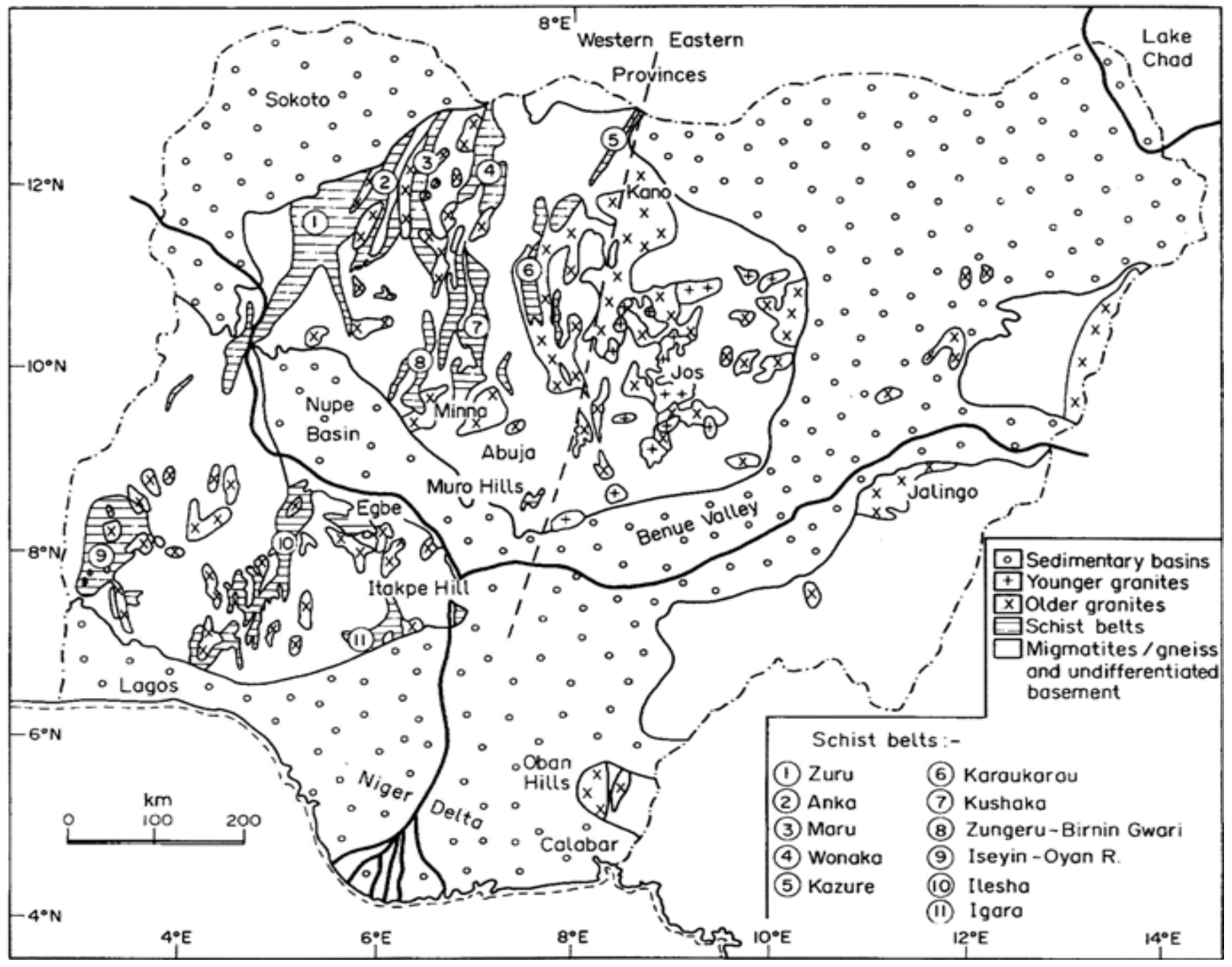

Fig. 2: Shist belt localities in Nigeria (Gold localities; After Woakes et al., 1986). 
Much of the country is laced with productive rivers. Nigeria's ecology varies from tropical forest in the south to dry savanna in the far north, yielding a diverse mix of plant and animal life. Inland from the southeastern coast are progressively higher regions $[1,2]$.

\section{Gold MetallogeniC PROVINCE IN Nigeria}

\section{Maru}

Two old gold mines are most important, and are within the Maru Schist belt. Duki Mine hosted by a shear zone traversing a quartzite-schist series, often exploitation of the $\mathrm{Si}$ Schistocity planes. The mineralization apparently made up of gold-quartz veins, was exploited by past miners for over $1 \mathrm{~km}$ of strike length, leaving behind series of collapsed N-S trending working without any surface exposures of the mineralization (figure 3).

There is no systematic correlation between gold mineralization and the type of country rock. Gold mineralization has been however, it is not worthy that the main areas of gold occur near faults and shear zones [3] (see also figure 2).

Recent explorations, drilling by the Nigeria Mining Corporation have shown the continuity of the gold-quartzsulphide veins below the old workings. The other old gold mine (Maraba) is a two sub-parallel quartz vein $(\sim 300 \mathrm{~m}$ long) system. Tourmaline and chlorite floats and altered wall rocks are the only indicators of mineralization, as there are no in situ exposures due to intensity of past mining.

\section{Anka}

In this area, there are a number of old gold mines, such as Kwali, Jameson, Zuzzurfa and Kuba, hosted by schists, Phyllites and quartzites of the schist belt. Individual veins or reefs seldom exceed $0.5 \mathrm{~km}$ of strike length as indicated by the extent of past workings, and are concordant with thehost rock foliation. These mineralized wallrocks shoe metal values in the following range [4]:

$\mathrm{Cu}=647-5410 \mathrm{ppm}, \mathrm{Pb}=7550-22600 \mathrm{ppm}, \mathrm{Ag}=1.58 .6 \mathrm{ppm}$, and $\mathrm{Au}=123-6320 \mathrm{ppb}$.

\section{Malele}

The Malele area is in the extreme southern part of the Maru Schist belt. Gold Mineralization occur in a NNE trending gold-quartz vein series cutting both biotite-gneiss and chlorite schist, now represented by a series of sub-parallel surface workings (pits, trenches and water ponds) with the vein exposures seldom observed. The mineralization was discovered in 1934 with the most prominent of the veins being $1.5 \mathrm{~m}$ thick, $370 \mathrm{~m}$ long and a grade of about $30 \mathrm{ppm}$.

\section{Tsofon Birnin Gwari and Kwaga}

The Tsohon Birnin Gwari and Kwaga gold sites are within the Kusshaka schist belt of north western Nigeria. While the Tsohon Birnin Gwari was an active gold mine in the 111930 s where over 600 ounces of gold were produced, the kwaga site is a recent discovery by artisanal miners following the extension of the tsohon Birnin Gwari gold reef system is about $7 \mathrm{~km}$ long, while the Kwaga reef system extends for about $3 \mathrm{~km}$. gold is mainly associated with pyrite and minor sphalerite, chalcopyrite, pyrrhotite, galena and magnetite.

The genuine is predominantly quartz, but K-felder and graphitic matter (from wall rocks) are so also constituents. Grades are very variable within the reef system and between oxide and ore zones, but generally 55-100 g/t Au are found (see figure 2).

Recent core drilling and near surface mine exposures have provided relatively fresh samples of the gol-quartz reefs and their altered wall rocks from which the geochemical characteristics of the Tsohon Birnin Gwari mineralization were studied (see figure 3)

\section{Bin Yauri}

Gold-sulphide-carbonate quartz veins occur in a birtle fault zone cutting horNfels of the contact of a Pan-African granodiorite batholiths intruding phyllites and tourmalinites of Zuru schist belt in northwestern Nigeria. Mineralization has been uncovered over a strike length of $1.5 \mathrm{~km}$ by past miners (1920s-1940s) [4].

Gold occurs associated with pyrite, chalcopyrite, galena and minor sphalerite, magnetite and bismuth telluride in a gangue of mainly quartz with some carbonates, sericite, chlorite and tourmaline. The gold veins are surrounded by a narriow zone of hydrothermal alteration in which a chloritetourmaline- pyritecarbonates [5, 6] association overprints a dominantly sericitic fabric of the hornfels wall rocks. Past mine records, reconnaissance exploration and studies have shown gold grades in the range 5-15ppm.

\section{Gurmana}

The Gurmana area of gold mineralization is situated in the extreme southern part of the Kushaka schist belt. Gold mineralization is in the form of quartz-sulphide veins and stock works hosted by amphibolites and gneisses. The gold quartz sulphide veins seldom extend more than a few tens of meters. Gold occurs with ryrite, chalcopyrite, galena, covelite and chalcosite.

\section{Okolom-Dogondaji}

The Okolom Dogondaji area of gold mineralization is in the Egbe-Isanlu schistbelt of southwestern Nigeria, and the primary gold-quartz veins and eluvial/alluvial placers have been mined extensively in the period 1930s-1950s. a series of gold-quartz veins is hosted by N-S and NNE-trending shear zones, which cut gneisses, [7] shists and amphibolites. The most prominent site is the Okolom old mine, which a goldsulphide-quartz reef system with a total strike length of about $3 \mathrm{~km}$ hosted by gneiss, amphibolites and take schist. Other sites in the (Dogondaji) area have relatively smaller veins hosted by amphibolites, gneisses, mica schists and phyllites. Gold is associated with pyrite, marcassite, pyrrhotite, chalcopyrite, argentite and galena, with a gangue of quartz tourmaline, sericite and chlorite [8].

\section{Iperindo}

The Iperindo old gold mine is in the Ilesha schist belt of southwestern Nigeria. The Iperindo mineralization comprises a series of auriferous quarz-carbonate veins localized by a subsidiary fault within biotite gneiss and mica schist, 
presently defined by sub-parallel old working extending overall for about $9 \mathrm{~m}$ in a NNE direction (see figure 3). Gold occurs with pyrite, pyrrhotite and minor chalcopyrite, galena, sphalerite, magnetite and ilmenite [9, 10]. Adjacent to the gold-bearing veins the host granite-gneiss has been hydrothermally altered to a sericite-chlorite epidote assemblage (also with hematite and pyrite)

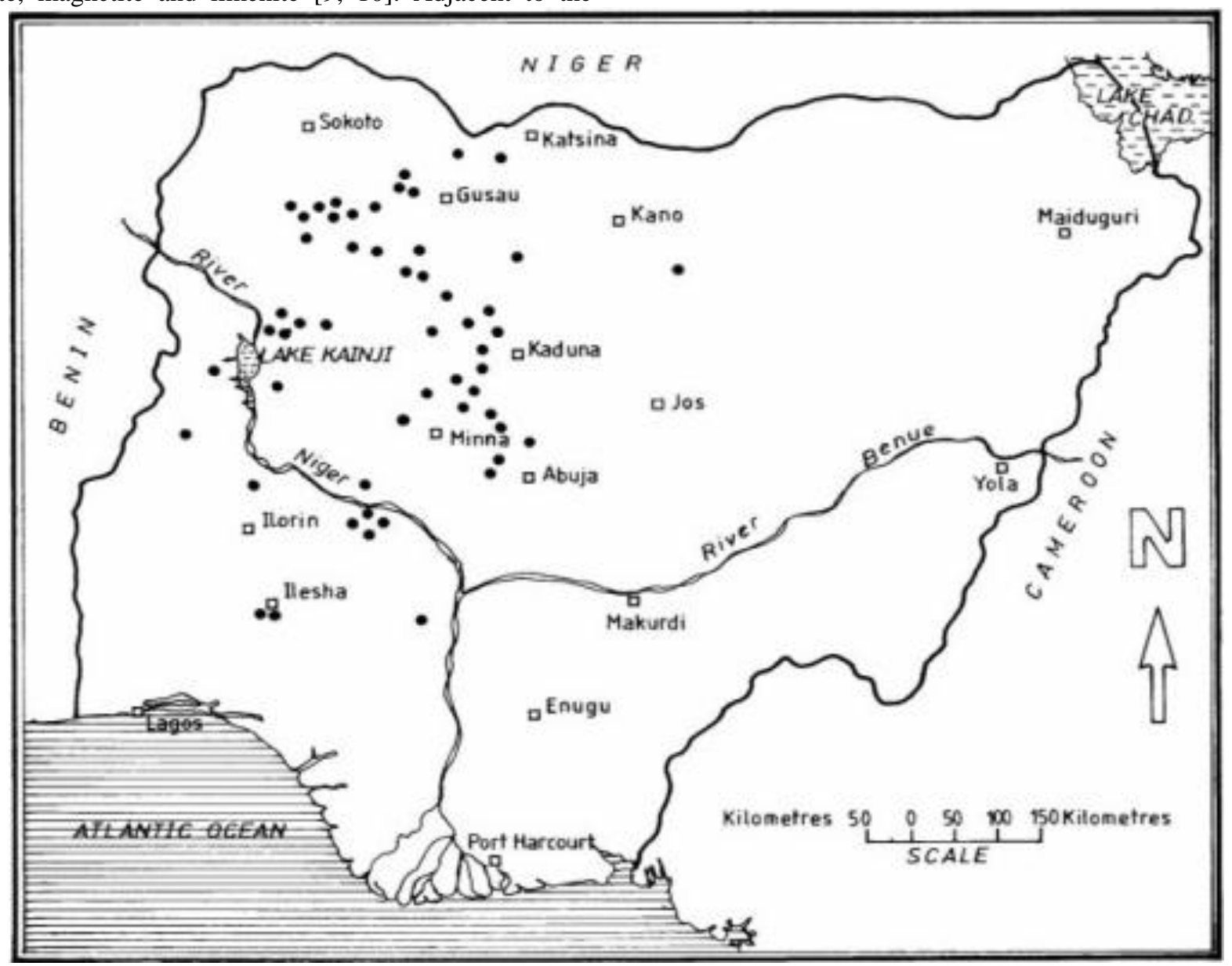

Fig. 3: Areas of gold mineralization in

Nigeria (Geological survey, 2009)

\section{Geologic Features OF Gold Deposits}

The following Geological Indicators are discussed below:

i. Color Changes: In many districts, acidic mineral solutions have bleached the area rocks to a lighter color. This can be an indicator of gold.

ii. Iron Staining \& Gossans: Not all veins produce much quartz-gold bearing veins can consist of calcite or mostly sulphide - which often weather into iron stained spots when the pyrites covert to iron oxides. Large amounts of iron oxides like hematite and ironstone can be favourable indicators.

iii. Quartz Vein Matter Accumulations: At times, small accumulations of quartz vein material can indicate mineralization in the area. This is a very common indicator (see figure 3).

iv. Productive Rock Types: The concept of favourable host rocks is an important one, but the types of rock which constitute "favourable" can vary a lot from one location to another ad can significantly different.

v. Rock Contact Zones and Faults: Many quartz veins and other hard rock gold deposits occur in zones along faults or at the contact of two different types or rock. vi. Correct Topography: As a general concept, the coarser gold does tend to hang up farther upstream. In the deserts, most of the best residual placers form in areas with moderate to flat slopes $[11,12]$.

vii. Extensions of known Mineral or Placer Areas: Other than pipe shaped bodies, most small scale gold deposits have a linear component. It is fairly common that new deposits can be found along this linear zone of deposition by looking for extensions along the line of deposition.

viii. Similar Geologic Area Nearby: If a certain rock type or geologic environment has been productive for gold in one area, and the same rock type or environment occurs a few miles away in the same mountain range, it may well be worthwhile to investigate (figure 3 ).

\section{Gold OCCURRENCE AND Mining Methods}

In Nigeria, gold occurs both as placers (alluvial and eluvia) and primary vein deposits within the schist belts of northwest and southwestern Nigeria. Some of the most important occurrences are at Maru, Anka, Kwaga, Gurmana, Birninyauri, Okolum, Dogon-Daji and Iperindo areas all associated with the schist belts. Personal field observation within the Kushaka schist belt showed that there are several new 
artisanal workings in places like Gusoro, Zumba, MaitumbiMinna [13], Pago and Maiwayo village which is almost at the contact between the basement and the Nupe sandstone.

It was also stressed that different types of rocks host Nigerian gold with superficially different petrographic characteristics and it accounted for why earlier workers stated that the Nigerian gold can be correlated with common host rocks from other parts of the world and likened their origin to that of the petrochemical characters of the host rocks. Identifying the appropriate structural patterns and hydrothermal processes necessary for gold fluid transport and deposition is important in gold exploration in Nigerian pan African basement [14].

It is concluded that the only controls of gold mineralisation in the Nigerian Pan African basement are essentially structural. These kind of consist of transcurrent fault systems, subsidiary faults along with other penetrative set ups together forming the overdue Pan Photography equipment conjugate fracture system [15]. These fault systems were probably the main force that the hydrothermal gold ore essential liquids were later focused into the subsidiary fault along with other structures, along which interactions in the fluids along with suitable walls rocks or even structures induced gold depositing. Furthermore it was observed that the regional failing structures tend to be largely not mineralized simply because they were areas of best fluid circulation and best fluid/rock quotients, whereas the actual genetically associated subsidiary set ups host the actual deposits for their decreased gold solubility as well as temperature [16].

The Schist belts are about the best-studied group of rocks in Nigeria because of the known mineralization such as gold, BIF, Marble, manganese etc. associated with them. Yet fundamental questions pertaining to the age, geodynamic setting of the belts remain unresolved.

\section{GOLD EXPLORATION METHODS}

Exploration of a Gold deposit invokes a series of systematic steps in converting a mineral occurrence into:

- Firstly a Mineral Prospect (indication of gold mineralisation supported by assays, width and length) [17]

- Then a Mineral Resources (Three dimensional exploration through drilling to indicate possible tonnage and grade)

- Mineable Ore reserves (completion of feasibility study and mine development to estimate proven tonnage and grade).

\section{A. Gold Exploration Processes}

The Gold Exploration processes involve:

$\sim \sim$ Use of Modern Exploration Method

$\sim \sim$ Pre-Feasibility Studies

$\sim \sim$ Feasibility Studies.

\section{ARTISANAl Mining Of GOLD AND EIA}

Any mining company ought to conduct a medical examination relative to immune systems, physiological habit and response to environmental changes of the field labourers/miners it engages. These medical examinations should be based on the geological, mineralogical, geochemical and toxicological reports after every mine activity. This was never done before. If done, this will surely protect the health conditions of the miners $[10,11]$

The Syn-mining EIA monitoring shall use equipments that could be used. The proposal could be based on the primary data gathered. The equipments to be used shall include Scintillation Counter and Geager Muller Counter which detect radiations.

\section{PRE-EIA AND EIA OPERATIONS}

Beyond adherence to philosophy, it is a pragmatic response to the lesson of experience from otherwise laudable projects which have turned into disasters because their potential negative impacts on the environment were not properly explored, and pre-emptive measures devised and applied [10]. The EIA operations in the study area should comprise the following:

Mineral mapping

$\sim$ Geochemical mapping

$\sim$ Toxicological studies

$\sim$ Futuristic continuation of toxicity disintegration.

These have radioactive elements with radioactive properties such as $\mathrm{Pb}, \mathrm{Cd}$, Th, etc. [12, 14]. They have the capacity to give adverse effects to humans and livestock in general if consumed $[4,9,17]$.

\section{DISCUSSION}

Exploration is now supported by a variety of advanced data integration and processing tools, from advanced 2D GIS platforms, which have the ability to display drilling data, to full blown 3D data Modelling processing and visualization packages.

Finally, people are the backbone of any good exploration approach. Not only do team members need to have the ability and experience, they must also understand the characteristics of the gold deposits they are searching for and be given sufficient field time to adequately test their targets.

Other factors such as an excellent understanding of proven exploration methods, effective use of technology, enthusiastic and responsible leadership, confidence in corporate direction, and attracting and training young professionals, are also import.

\section{CONCLUSION}

The paper examines how gold metallurgenies are known in Nigeria. It was really observed that despite potentials of highly graded gold deposits Nigeria is faced with challenges of illegal Artisanal mining which depletes the deposits. The Federal Government of Nigeria and the States and Local Governments, and other non-governmental stke-holders must protect gold deposits through a well co-ordinated management strategy that will prevent its mismanagement such as illegal mining as mentioned above etc. Government needs to chart ways to tackle this menace for a better survival of the deposits. 


\section{RECOMMENDATIONS}

It is recommended that the following should be executed:

Regional and detailed geochemical surveys including sampling of stream sediments, different layers of soil, rock, water, plants, termite mounds etc. to identify possible targets and geochemical patterns associated with the mineralised zones, body model and Resource estimation.

Study of Remote Sensing Data such as Land sat imagery, Aster and Hyper spectral data.

Air bone geophysical surveys using magnetic, gravity, electromagnetic and seismic techniques,

Regional and detained geological and structural mapping of various rock types and associated geological structures controlling mineralization,

Sampling of surface outcrops to understand if there are any anomalous concentration of mineral/metals,

Multi parametric ground Geographical exploration techniques such as ground magnetic, induced polarization, Gravity Seismic Radiometric, Resistivity Surveys, Trenching to expose the concealed mineralised. Zones, Drilling including diamond core, Reverse Circulation, RAB, Trenching and multi element chemical analysis. The exploration results culminate with drilling to understand the third dimension of the mineralised zones, and data processing using $2 \mathrm{D}$ and $3 \mathrm{D}$ geological software to define the $3 \mathrm{D}$ ore.

\section{REFERENCES}

[1] Hilson, G. (2006). The socio-economic impacts of artisanal and smallscale mining in developing countries. Taylor \& Francis.

[2] Nigeria Geological Survey Agency, (2006).Geological Map of Nigeria.Federal Ministry of Solid Minerals Development.

[3] Carboo, D. \& Serfor-Armah, Y. (1997). Arsenic in Stream and Sediments in Obuasi Area. Proceedings of the symposium on the mining industry and the environment KNUST/IDRC. $114-119$.

[4] Amegbey, N.A. \& Adimado, A.A. (2003). Incidents of cyanide spillage in Ghana. Mineral Processing and Extractive Metallurgy, 112(2), 126 130. http://dx.doi.org/10.1179/037195503225002808

[5] Cleary D. \& Thornton I. (1994). The Environmental impact of gold mining in the Brazilian Amazon. In Issues in Environmenta Science and Technology (R. E. Hester and R.M. Harrison, ed.), 1: 17.

[6] Garba, I. (1988). The variety and possible origin of the Nigerian gold mineralization: Okolom, Dogondaji and Waya veins as case studies. Journal of African Earth Sciences, 7, 981-986. http://dx.doi.org/10.1016/0899-5362(88)90011-5

[7] Kinniard, J.A. (1984).Contrasting styles of Sn Nb Ta-Zn mineralization in Nigeria. Journal of African Earth Sciences.2:81-90. http://dx.doi.org/10.1016/s0731-7247(84)80001-4

[8] Lacerda, L.D. \& Marins, R.V. (1997). Anthropogenic mercury emissions to the Atmosphere in Brazil: The Impact of Gold Mining. Journal of GeochemicalExploration.58: 223-229. http://dx.doi.org/10.1016/S0375-6742(96)00068-4

[9] Manu, A.T. Wumasi, Y.A. \& Coleman, T.L. (2004). Application of Remote Sensing and GIS Technologies to Assess the Impact of Surface Mining at Tarkwa, Ghana.

[10] Hilson, G. (2006). The socio-economic impacts of artisanal and smallscale mining in developing countries. Taylor \& Francis.

[11] Aigbedion, I. and Iyayi, S. E. (2007) Environmental effect of mineral exploitation in Nigeria. International Journal of Physical Sciences, 2 (2), 33-38.

[12] Caravanos, J., Clark, E., Fuller, R. \& Lambertson, C. (2011). Assessing worker and environmental chemical exposure risks at an e-waste recycling and disposal site in Accra, Ghana. Journal of Health and Pollution. 1 (1), 16-25. http://dx.doi.org/10.5696/jhp.v1i1.22

[13] Adelekan, B.A. \& Abegunde, K. D. (2011). Heavy Metals Contamination of Soil and Groundwater at Automobile Mechanic
Villages in Ibadan, Nigeria. International Journal of Physical Science, 6 (5), 1045-1058.

[14] Garba, I. (1988). The variety and possible origin of the Nigerian gold mineralization: Okolom, Dogondaji and Waya veins as case studies. Journal of African Earth Sciences, 7, 981-986. http://dx.doi.org/10.1016/0899-5362(88)90011-5

[15] Garba, I. (1992). Rare earth element study of Bin Yauri gold deposit, Nigeria.Transactions of theInstitution of Mining and Metallurgy (section B:Applied Earth Sciences), 101(B), 158-161.

[16] Darma, M. R., Kankara, I. A. and Shazali, N (2016): Potentials of Gold Mining and Extraction Methods in Nigeria. A paper presented at the First Umaru Musa Yar'adua National Economic Development and Poverty Eradication Conference, between $5^{\text {th }}$ to $7^{\text {th }}$ May, 2016.

[17] Darma, M. R. and Kankara, I. A. (2016): Effect of Artisanal Gold Mining at Maiwayo Environ, Northern Nigeria: Implication for Environmental Risk. Nigerian Strategic Conference on Economic Development Policies, Economic Performance and Sustainability; Theme: 55 years Sectoral Performance Appraisal of The Nigerian Economy: Issues, Challenges \& Prospects February, $24^{\text {th }}-26^{\text {th }}, 2016$, held at University of Abuja, Gwagwalada, Abuja, Nigeria.

\section{Brief Biography of the Author}

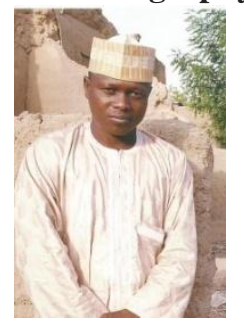

Dr. Aliyu Ibrahim Kankara was born at Kankara in Katsina State Nigeria on Friday $20^{\text {th }}$ December, 1968. He was educated at Ahmadu Bello University Zaria, Nigeria and Bayero University Kano-Nigeria where he obtained BSc. Geology and MSc. Land Resources Development in 1994 and 2001 respectively. In 2014, he earned $\mathrm{PhD}$ degree in Geology with specialization in Mineral Exploration from Federal University of Technology Minna Nigeria. Dr. Aliyu worked as Unit Head, Rural Water Supply In the Works Department of Kankara Local Government, Katsina State from 1990 to 1996. He Taught Chemistry and Physics as a classroom teacher at the Government Girls Senior Science Secondary School (GGSSSS) Sandamu Katsina State, under State Ministry of Education in 1996, before moving to the prestigious Kaduna Polytechnic as a LECTURER in the College of Engineering, Department of Mineral Resources Processing, where he taught all geologybased Disciplines, between 1996 to 1999. Between 1999 to 2001, Aliyu worked as PROJECT GEOLOGIST at the CGC Nigeria Limited Katsina and Sokoto offices. He was back to classroom as Chemistry and Geography Master at Government Day Secondary School Dandume and Government Girls Secondary School Daudawa both in Katsina State, between 2001 to 2006. He was temporarily seconded to Basic Agriculture and Soil Science Training College, Daudawa, Katsina State (Part Time) between 2004 to 2005. He was a LECTURER II at the Dept. of Geography, Umaru Musa Yar'adua University, Katsina, between 2006 to 2012. He is currently a SENIOR LECTURER, Department of Geography and Regional Planning, Federal University Dutsinma, Nigeria. He has published about 23 articles in reputable journals, some of which are listed below:

1. Kankara, I. A. and Farouk, H A. (2015) Provisional Dating of Metasedimentary Rocks in South Katsina State, Northwestern Nigeria: Studies in Proterozoic Crustal Evolution. Journal of Physical Sciences and Environmental Studies. Vol. 1 (4), pp 55-61, October 2015 ISSN 2467-8775. Review http;// pearlresearchjournals.org/journals/index.html.

2.Kankara, I. A., Darma, M. R and Abdullahi, S. (2016) Effect of Artisanal Gold Mining at Maiwayo Environ, Northern Nigeria: Implication for Environmental Risk. International Journal of Advanced Studies in Ecology, Development and Sustainability. ISSN- Hard Prints: 23544252. Online: 2354-4260. Vol. 4 No. 1 April 2016.

3. Darma, M. R., Kankara, I. A., Adamu, A. Gambo, G. and Gafia B. A. (2016) Perception of Safety and Security of Economy of Africa: Shortfall in Solid Mineral Exploitation in Contemporary Nigeria. Social Science Journal of Policy Review and Development Strategies. Hard Prints: 2488-9636. Online: 2488-9628. Vol. 2 No. 1 April 2016.

4. Kankara, I. A., Bazza, L. M. and Garba, I. (2016). Examining Groudwater Pollution in Central Katsina City. A paper published in the Journal of Hydraulic Engineering 1 (2016) doi $10.1726523 \quad 32-82$ 15/2016.01.003. ISSN: 2332-8215. Website: http://www.davidpublishers.org/Home/Journal/JHE. Vol. 1 No. 1, Jan.March 2016 (Serial Number 2) He has also published three (3) books:

1. The Geology, Geography and Mineral Resources of Katsina State, Nigeria (Katsina, Katsina: Labson Production Kaduna, 2014) 
2. Dictionary of Earth Sciences (Katsina, Katsina: Naja'atu Publishers, Katsina, 2015) and

3. Dictionary of Geological Sciences (Katsina, Katsina: Naja'atu Publishers, Katsina, 2015) His research interests are areas of Geochemistry, Hydrogeology/Hydrology and water Resources Development.

Dr. Kankara has obtained many awards, such as:

1. Science/Geography Tutor, Refresher Courses, Funtua, Katsina State, 2003-2005

2. Participant, WAEC and NECO marking, 2006 to 2008.

3. Science/Geography Tutor, JAMB Clinic Program, Daura zone, Katsina State, 2011

4. Science/Geography Tutor, Govt. College Katsina, Katsina State, 2011

5. INEC Ad hoc Staff (Returning/Collation officer) for 2011 General Elections.

6. Guest of the Week, Science Program, Bauchi State Television, 19/2/2013

7. Guest Speaker, $9^{\text {th }}$ Graduation and Annual Lecture of Katsina Vocational Centre, 14/8/2009

8. Guest Speaker, $12^{\text {th }}$ Graduation and Annual Lecture of Katsina Vocational Centre, 30/8/2012

9. Guest Speaker, $14^{\text {th }}$ Graduation and Annual Lecture of Katsina Vocational Centre, 18/11/2014

10. INEC Ad hoc Staff (Returning/Collation officer) for 2015 General Elections.

11. Guest Speaker, Seminar Series of Humanities, Umaru Musa Yar'adua University, Katsina, $2 / 12 / 2010$

12. Guest Speaker, Seminar Series of Humanities, Umaru Musa Yar'adua University, Katsina, 26/5/2011

13. Chairman, Association for Humanitarian Services and Environmental Protection, Katsina

State (AHUSEP)

14. Chairman, Electoral Committee of the Election of Leaders Association of Nigerian Authors (ANA) Katsina State Chapter, 2016. Dr. Kankara is also the author of Author, Shata Ikon Allah, and Mahadi Mai Dogon Zamani: Shata Da Kundin Wakokinsa. Biographies of Late Hausa Music Icon, Dr. Mamman Shata Katsina 2006 and 2013, and 30 other books written in native Hausa and English languages. 